\title{
God and the Pandemic
}

\section{Renata Kárníková}

WRIGHT, N. T. God and the Pandemic: A Christian Reflection on the Coronavirus and Its

Aftermath. London: Zondervan, 2020. ISBN 978-0-310-12081-0

DOI: $10.5507 /$ epd.2021.017

Pandemie koronaviru zasáhla v roce 2020 celý svět. Profesor Tom Wright z University of St. Andrews ve Skotsku napsal knihu o 76 stranách s názvem Bůh a pandemie. Křestanská reflexe na koronavirus a její následky. Publikace vznikla jako vzpomínka na Simona Barringtona, biskupa, který umřel 11. dubna 2020 na Covid-19.

Cílem knihy je zamyšlení nad otázkami kolem pandemie. Hlavním smyslem je hledat důvody pandemie a odpovědi na důvody vzniku s pomocí Biblických příběhů. Proč to Bůh dopouští? Kniha je rozdělena na pět kapitol. Autor citacemi z bible přirovnává současnou situaci k historii lidstva. Předkládá biblické příběhy, které se vztahují k současné situaci kolem koronaviru, hledá a nabízí odpovědi, ale nechává čtenáři prostor pro vlastní reflexi a sebereflexi.

První kapitola s názvem „Kde začneme?“ se ohlíží do minulosti na pandemie SARS nebo Nemoc šílených krav, které svět nedávno zasáhly. Rekapituluje postup koronaviru ve světě. V druhé kapitole autor citacemi z Bible analyzuje stav současné situace. Rozebírá příčiny a následky věcí. Jedno z významných slov Nového Zákona je slovo „nyní". Touto větou začíná třetí kapitola „Ježíš a evangelia“. Nabádá, aby lidé radikálně změnili své cesty. Je potřeba, aby se lidé modlili nejen, když přijde katastrofa, ale každý den. Je potřeba, aby přijali Ježíše do svého života. Biblické př́iběhy poskytují odpovědi na otázky. Existuje mnoho spekulací a argumentů k biblickému vysvětlení velkých a zničujících událostí. Bůh chce upozornit na to, že špatně nakládáme s tímto světem. Autorovi se zdá velmi potřebné, abychom četli evangelia z Poslední večeře, které obsahují slova života, ale i slova varování. Všichni dobře víme, že Ježíš zemřel za naše hříchy. Ve čtvrté kapitole autor poukazuje na to, co je třeba udělat. Předkládá vzory, ve kterých bychom mohli hle- 
dat odpovědi na naše současné problémy. Zhřešili jsme a potřebujeme pokání. Zhřešili jsme tím, že špatně zacházíme se životem, se životním prostředím. Měli bychom se ptát, jak pomoci. Lidé rádi sledují katastrofy. A pak se diví, proč i jim se stávají, proč to Bůh dopustí. Autor doporučuje vidět krizi, vydržet ji a nesnažit se o zásadní změny života. Koronavirus a její následky přirovnává k porodu. Vybírá si svou daň mnoha úmrtími, ale také stresem a strádáním milionů lidí. Ptá se, co by měl být úkol církve samotné. Církev by se v současné době měla především modlit. Současnost je druh exilu, druh půstu, nejistot a nevědomosti. Má pocit, že se jedná o hluboce křestanskou verzi Sokratova principu: netvrdil, že toho ví hodně, i když se neustále vzdělával, i přesto říkal: „Vím, že nic nevím.,', a tak pokládal otázky.

„Kam směřujeme? Proč musíme naříkat?", je název poslední kapitoly. V době akutní krize je čas nářků. Pláče-li někdo, plačte s ním, protože smutek je součástí lásky. Nesmutnit, ani nenaříkat, znamená uzavřít své srdce. Ze srdce pochází samotná láska. Musíme být silní a pokračovat dál. Silní tak, jako Duch, který zvedl Ježíše z mrtvých. Máme čekat. Čekat v lásce, víre, naději a v nevědomosti. Veškeré pohodlí, které snadno získáme, je klam, protože nechceme čelit temnotě. Bůh je svrchovaný a my neznáme jeho plán. Určité skupiny lidí využívají neznámý boží plán ve svůj prospěch.

Dřive takové epidemie přicházely a zase odcházely. Až moderní věda dokázala viry a bakterie identifikovat, lidi proočkovat a provádět další preventivní opatření. Pokud jsme se domnívali, že moderní technologie a věda eliminují takovéto nemoci, očividně jsme se mýlili. Navíc je důležité si uvědomit, že současná pandemie není o hrdinství. Je potřebná velká dávka sebereflexe, aby nedocházelo skrze zdánlivé hrdinství a pomoci k ještě větší katastrofě a dalšímu masivnímu šiření. Důležitá je kooperace lékařů a duchovních, obzvlášt' v případech, kdy jsou lidé blízko smrti.

Přítomný okamžik je jako doba vyhnanství. Bankroty, obrovské sociální a politické boje, hladomory, nezaměstnanost, sociální malátnost bude dříve či později to, čím budeme muset všichni procházet. Autor nabádá, abychom analyzovali situaci, načrtli vizi, jak ji řešit. Klade velký důraz na moudré státnické vedení v kooperaci s křest’anskými vůdci. Přemýšlejme o výzvách, kterým budeme vystaveni v další době. Upozorňuje na sociální nerovnosti, na mamon a ziskuchtivost bohatých a zároveň na chudé, kteří budou ještě chudší. Doufá v moudré lidské vedení a iniciativu. Spekulace „Kdo za to může?" zůstávají zatím nezodpovězeny. Tom Wright upozorňuje na to, že je to výzva k pokání, př́ležitost ke standardnímu druhu evangelizace. Žádá rádné vyšetřování a odpovědnost za vše, co způsobilo únik viru.

Hluboké zamyšlení, velká pokora, naděje, víra, láska, důvěra, usmíření, spása, řešení, moudrost poučení, problém zla, smrt, vzkříšení, odpuštění, prozřetelnost, sebereflexe, zodpovědnost za své činy, četba mezi raádky, citace ze Starého a Nového zákona jsou nedílnou součástí této jedinečné knihy. 